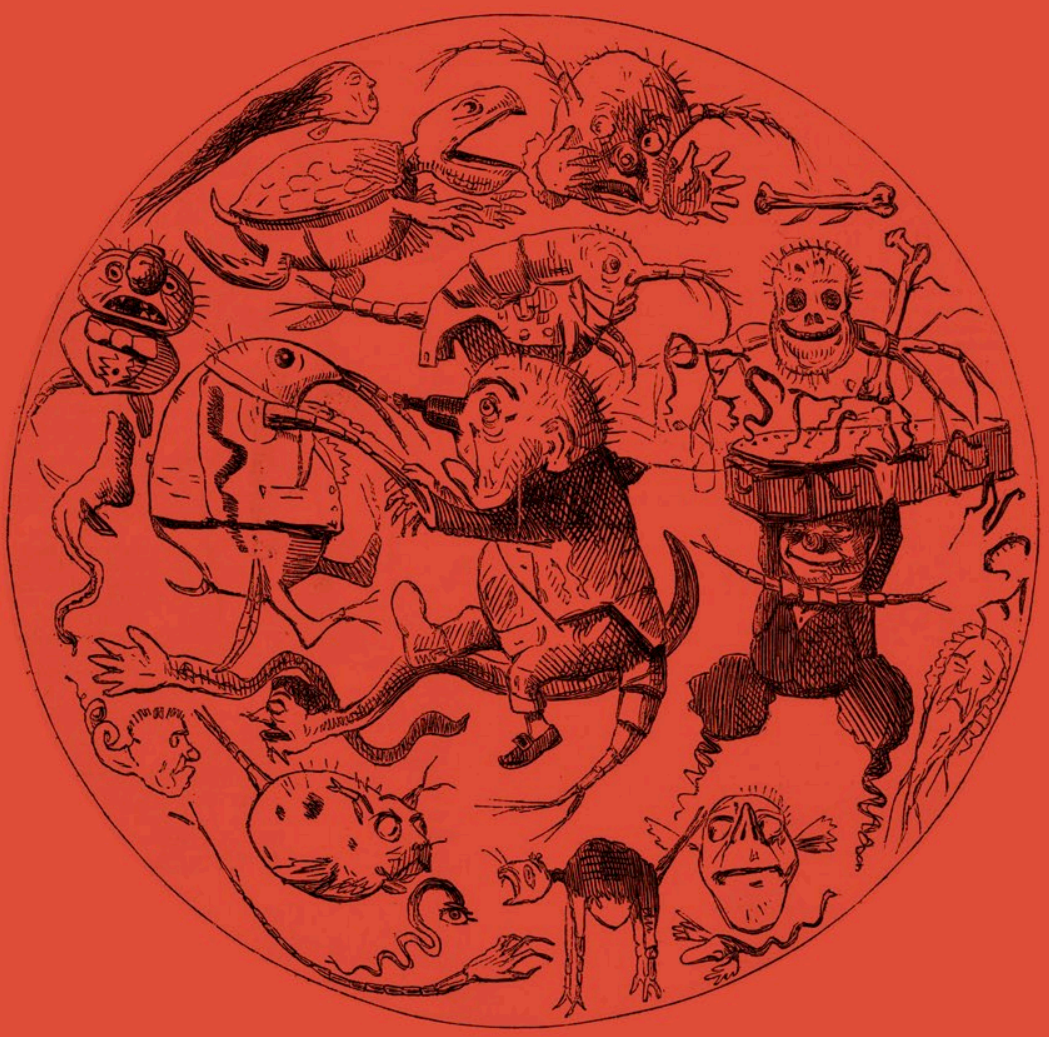

Edited by Melissa Dickson, Emilie Taylor-Brown, and Sally Shuttleworth Progress and pathology Medicine and culture in the nineteenth century 


\section{Progress and pathology}

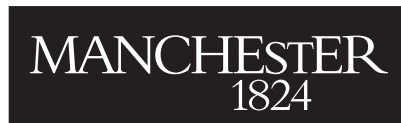

Manchester University Press 


\section{S) HN}

\section{SOCIAL HISTORIES OF MEDICINE}

Series editors: David Cantor and Keir Waddington

Social Histories of Medicine is concerned with all aspects of health, illness and medicine, from prehistory to the present, in every part of the world. The series covers the circumstances that promote health or illness, the ways in which people experience and explain such conditions, and what, practically, they do about them. Practitioners of all approaches to health and healing come within its scope, as do their ideas, beliefs, and practices, and the social, economic and cultural contexts in which they operate. Methodologically, the series welcomes relevant studies in social, economic, cultural, and intellectual history, as well as approaches derived from other disciplines in the arts, sciences, social sciences and humanities. The series is a collaboration between Manchester University Press and the Society for the Social History of Medicine.

\section{Previously published}

The metamorphosis of autism Bonnie Evans

Payment and philanthropy in British healthcare, 1918-48 George Campbell Gosling

The politics of vaccination Edited by Christine Holmberg, Stuart Blume and Paul Greenough

Leprosy and colonialism Stephen Snelders

Medical misadventure in an age of professionalization, 1780-1890 Alannah Tomkins

Conserving health in early modern culture Edited by Sandra Cavallo and Tessa Storey

Migrant architects of the NHS Julian M. Simpson

Mediterranean quarantines, 1750-1914 Edited by John Chircop and Francisco Javier Martínez

Sickness, medical welfare and the English poor, 1750-1834 Steven King

Medical societies and scientific culture in nineteenth-century Belgium Joris Vandendriessche

Managing diabetes, managing medicine Martin D. Moore

Vaccinating Britain Gareth Millward

Madness on trial James E. Moran

Early Modern Ireland and the world of medicine Edited by John Cunningham

Feeling the strain Jill Kirby

Rhinoplasty and the nose in early modern British medicine and culture Emily Cock

Communicating the history of medicine Edited by Solveig Jülich and Sven Widmalm

Melissa Dickson, Emilie Taylor-Brown, and Sally Shuttleworth - 9781526147547 


\title{
Progress and pathology
}

Medicine and culture in the nineteenth century

\author{
Edited by \\ Melissa Dickson, Emilie Taylor-Brown, \\ and Sally Shuttleworth
}

Manchester University Press 


\section{Copyright (C) Manchester University Press 2020}

While copyright in the volume as a whole is vested in Manchester University Press, copyright in individual chapters belongs to their respective authors.

This electronic version has been made freely available under a Creative Commons (CC-BY-NC-ND) licence which permits non-commercial use, distribution and reproduction provided the editors, chapter authors and Manchester University Press are fully cited and no modifications or adaptations are made. Details of the licence can be viewed at https://creativecommons.org/licenses/by-nc-nd/4.0/legalcode

Published by Manchester University Press Altrincham Street, Manchester M1 7JA

www.manchesteruniversitypress.co.uk

British Library Cataloguing-in-Publication Data

A catalogue record for this book is available from the British Library

ISBN 9781526133687 hardback

ISBN 9781526147547 open access

First published 2020

The publisher has no responsibility for the persistence or accuracy of URLs for any external or third-party internet websites referred to in this book, and does not guarantee that any content on such websites is, or will remain, accurate or appropriate.

Cover image: Punch, 'A drop of London water'. Credit: Wellcome Collection. CC BY Cover design: riverdesignbooks.com

Typeset

by Toppan Best-set Premedia Limited 